\title{
Ainda é tempo de Glauber!
}

\author{
Por Rosana Kamita
}

Paloma Rocha é filha de Glauber Rocha e está integrada ao Projeto Tempo Glauber, museu com arquivos e acervo do cineasta, centro de referência para pesquisas que surgiu pela iniciativa de sua mãe, Lúcia Rocha. $\mathrm{O}$ acervo garante a preservação de uma relevante contribuição artística e se constitui, também, em um registro da história do país. A obra do cineasta transpõe fronteiras e a manutenção desses documentos propicia investigações e apreciações de muitas vertentes, cinematográficas, literárias, sociológicas, antropológicas, filosóficas, entre outras. Tempo Glauber colabora diretamente com a cultura nacional e internacional ao disponibilizar e recuperar as criaçóes do cineasta de Deus e o Diabo na Terra do Sol e Terra em Transe.

1. O Tempo Glauber abriga as criações artísticas do cineasta em outras frentes, como poemas e textos teatrais. Qual encaminhamento será dado a estes materiais? Serão publicados ou disponibilizados (como parte deles já se encontra) no endereço eletrônico do museu?

Em primeiro lugar quero agradecer a oportunidade desta entrevista. Como vocês bem observaram, o caráter do Tempo Glauber é o de uma instituição que preserva e divulga o acervo de Glauber Rocha, que se constitui de seus 22 filmes e cerca de 100 mil documentos, a maioria inéditos. Desde o ano de 2003, a Petrobrás, através dos incentivos fiscais da Lei Rouanet, vem investindo na recuperação e revitalização deste patrimônio cultural em dois projetos:

-Coleção Glauber Rocha Fase 1 - restauração e difusão digital dos filmes Deus e o Diabo na Terra do Sol, Terra em Transe, (já lançados), O Dragão da Maldade Contra o Santo Guerreiro, Barravento e A Idade da Terra (com lançamento previsto em DVD até o final de 2007). Os DVDs são sempre duplos e todos trazem um documentário a respeito de cada filme, sempre repletos de entrevistas, desenhos, fotos e documentação geral e inédita do Tempo Glauber. 
Os documentários são dirigidos por Joel Pizzini e por mim.

- Projeto Tempo Glauber - Revitalizando a Cultura, iniciado recentemente em abril de 2007, que em parceria técnica com o Arquivo Nacional e a Cinemateca Brasileira, está trabalhando na conservação preventiva dos originais e construindo um depósito climatizado para sua salvaguarda. 0 Projeto ainda prevê a digitalização integral do acervo para consulta pública e gratuita através do site: www.tempoglauber.com.br, e também em sua sede na Rua Sorocaba 190. Botafogo, Rio de Janeiro.

2. Os filmes de Glauber mantêm interesse e atualidade impressionantes, principalmente se levarmos em conta o fato de pertencermos a um país que se autodenomina "sem memória". Os filmes permanecem atuais ou as questões tratadas em seus temas se eternizam de alguma forma?

Claro, a obra de Glauber além de atual é visionária em previsões políticas e inovações estéticas. Em toda as suas manifestações artísticas, seja ela cinematográfica, literária ou no campo das artes plásticas, estão sempre presentes os conflitos da humanidade, a desigualdade social, os movimentos revolucionários, as reflexões existenciais, o colonialismo, expressas através de signos-símbolos do imaginário popular brasileiro, latino-americano, africano e europeu, entre outros que emergem de sua própria pulsão criativa.

3. A partir do acervo deixado por seu pai, quais as principais inferências que podemos ter sobre o processo criativo que ele adotava? Há algum registro em especial que seja mais revelador nesse sentido?

Uma parte desta pergunta foi respondida anteriormente. Através dos documentários produzidos para o lançamento dos filmes restaurados em DVD, revelamos aspectos do processo criativo do artista. Glauber era um grande produtor e administrador, o que possibilitou uma trajetória livre dos esquematismos do mercado.

No seu último filme, $A$ Idade da Terra, ele mesmo revela seu processo de criação cinematográfico, interferindo nas filmagens, rompendo com a narrativa convencional e propondo uma integração entre o artista e sua obra, criador e criatura.

4. Oposicionamento de Glauber com o Cinema Novo e o período bistórico-social do Brasil da época nos permite afirmar que sua atuação no cenário nacional foi fundamental naquele momento histórico. Atualmente, com o Tempo Glauber, pesquisas, publicações e tudo o mais que cerca o nome do cineasta, Glauber, continua fazendo bistória?

Sem dúvida, as revelações que estão sendo feitas a partir da restauração da obra de Glauber contribuem para a história ou alertam para o fato de que as mudanças ocorridas nos últimos 30 anos foram irrelevantes ou ineficazes, ou seja, pela sua proposta libertária para a linguagem do audiovisual. Às vezes somos obrigados a exercer alguma seleção na divulgação destes originais. Glauber pode incomodar mais morto do 


\section{Itha de Santa Catarina}

que vivo.

5. Tempo Glauber ou Tempo de Glauber? Que aproximações podem existir entre tempo, memória e o cineasta?

Tempo Glauber, no tempo de Glauber, Glauber e sua morada no tempo, ainda é tempo de Glauber!

6. A morte prematura do cineasta, o engajamento em um contexto bistórico-social e cultural de um Brasil em que forças ditatoriais e ideológicas se digladiavam e a utilização de sua arte como tentativa de interferir e alterar a realidade são fatos que poderiam de alguma maneira ter contribuido para torná-lo uma figura dramática, uma persona Glauber, acima de sua obra?

Glauber Rocha é uma figura mítica. Muito se falou e pouco se viu. Agora poderemos assistir a seus filmes e compartilhar de suas idéias e criaçóes. Interagindo ou rejeitando Glauber, a história continua.

7. Através do acervo deixado pelo cineasta é possivel saber quais projetos Glauber tinha a intenção de desenvolver? Há o registro de obras em andamento que ficaram inacabadas?

Acredito que Glauber tinha intenção de realizar e desenvolver todos estes projetos, visto que no processo de catalogação do acervo, na maioria das obras já verificamos diversos tratamentos e versões. Ressalto alguns: A Conquista de Eldorado, A Conquista do ParaYso, Moloch, Jango, o destino da Humanidade, dentre outros.

8. Para você, qual seria o maior legado de Glauber Rocha para o cinema em geral e o cinema brasileiro em particular?

O "Triunfo da Beleza e da Justiça!", com diz Paulo Martins no final de Terra em Transe. 